\title{
12. Our custodial role for the quality of advisory relations at the centre of government $^{1}$
}

\author{
Patricia Scott
}

Patricia Scott joined the APS in 1990. Her APS career included substantial periods in the Department of the Prime Minister and Cabinet and in line agencies including the Department of Industry, Tourism and Resources. She was subsequently appointed the inaugural Secretary of the Department of Human Services in 2004. She was appointed Secretary of the Department of Communications, Information Technology and the Arts in May 2007 before being appointed Secretary of the Department of Broadband, Communications and the Digital Economy in December of that year. In August 2009 she was appointed a Commissioner of the Productivity Commission.

I have had the privilege of serving five years as a secretary, four prime ministers and fourteen other ministers. For more than a decade, over the Keating and Howard governments, I was a frequent cabinet note-taker. Throughout this diverse experience I gained insights into the strengths of the Australian version of the Westminster system based on a rigorous, well informed cabinet process; and insights into the risks and problems created when good cabinet process is abandoned.

Also of vital importance to good governance are: clear lines of ministerial, ministerial adviser and public service accountability; respect for the respective strengths and roles of each; and recognition by ministers of the value of experienced, frank and fearless advice.

\section{A rigorous cabinet process}

I am a strong advocate for substantive cabinet consideration of all major policies on the basis of written submissions (not PowerPoint slides) and for rigorous coordination comments by all relevant departments. There are three key points to be noted here:

1 This paper was written by Patricia Scott in May 2011. 
1. Written submissions formulated through genuine agency consultation allow a wider set of issues to be aired, key differences of view and risks to be considered and balanced recommendations to be formulated.

2. I consider it essential that the coordination comments provided by departments on cabinet submissions are not cleared by ministers or their ministerial advisers and that they be available to all cabinet ministers. This ensures that cabinet has the frank views of relevant departments.

3. Informed decision-making needs to be based on the consideration by ministers of the evidence and a variety of views, and not just the views of ministerial advisers and a limited few in central agencies.

No sensible individual would make a substantial financial decision on the basis of a PowerPoint presentation or a short paper. Why would it be fine then to have senior ministers or cabinet make decisions on that basis without substantive written analysis and alternative commentary available to them? Very infrequently there will need to be exemptions (national emergencies, global crises or unforseen urgencies), but over the last 20 years some of the worst decisions I have seen were done by dint of desperation, with insufficient written analysis, by a 'kitchen cabinet' or a select few ministers under intense secrecy (often without the benefit of implementation considerations or the valuable advice of agencies with program and stakeholder engagement experience).

Moreover, too often advice from line ministers and their departments has been undervalued by central agencies and such 'kitchen cabinets', resulting in a disempowerment of ministers and a subsequent detrimental impact on lines of accountability and implementation.

And while some good decisions have been made in such circumstances, one should only take such risks when forced to rather than making it the standard process. Policy making is at its weakest, and policies likely to be most compromised, when cabinet is merely a rubber stamp.

\section{The role of public engagement}

There should be the opportunity not only for well informed debate in the cabinet, but, on very significant reforms, also an opportunity for informed input from key stakeholders and the general public.

It might seem old-fashioned to develop proposals for public consultation (the old green paper) followed by further government consideration and then the release of the final policy detailed document (the white paper) but why not engage the general public, academia and stakeholders? As Gary Banks, 
Chairman of the Productivity Commission recently noted, 'the experience has been that consultation is valuable not only to develop and get acceptance for broad reform options, but also to get the detail right in the option that is finally implemented. ${ }^{2}$

My own experience in the Productivity Commission's study and public inquiry process is that there is much to be gained from transparent and robust engagement.

\section{Good policy advice}

Of course, good policy development starts a long way before cabinet. My singular piece of advice to young policy advisers and aspiring politicians is to take a few hours to learn and understand the basic economic framework regarding government policy. It doesn't matter if your policy expertise is not economics - all policy making involves making choices and opportunity costs. And the first place an economist wants to start is with the clear identification of the problem.

Unfortunately too many political advisers and public servants instead start with a solution before they have analysed the causes and the extent of the problem. In terms of basic economic principles, a few basic questions should always be asked:

- What is the problem, its extent and consequences? Who wins and who loses?

- Is the problem created by market failure?

- If so, which type of market failure as this would affect the remedy (externalities, public good characteristics, ill-defined property rights, barriers to entry or exit, insufficient information)?

- Is it an equity issue? What is the equity outcome being sought by the government?

- Will government intervention help or hinder a solution?

- Will the gains exceed the costs?

- Who needs to be consulted?

2 Banks, G. 2011, Successful Reform: Past Lessons, Future Challenges (Annual Forecasting Conference of the Australian Business Economists, 8 December 2010), Productivity Commission, Canberra (http://www.pc.gov. au/_data/assets/pdf_file/0018/104229/successful-reform.pdf). 
With the benefit of hindsight

And if the analysis suggests government intervention, what is the appropriate form of intervention (encouragement of private sector activity, direct government provision, regulation, tax, subsidy, funding to a non-government organisation, public private partnership, a fee for service, or a government ban)?

Furthermore, how should the intervention be implemented and by whom? Who needs to be involved in implementation? What is the sensible implementation timetable? What are the risks, and how can they be mitigated, and at what cost? What will be delivered and when?

And ultimately, will this intervention really address the problem? What will be the behavioural response of producers and/or consumers? What are the likely unintended consequences?

More generally, what is the opportunity cost of addressing this problem now relative to the other priorities of the government and how does it fit within a longer-term, strategic view of policy priorities?

Systematically addressing a problem this way may have a tinge of Bernard in Yes Minister asking too many awkward questions. But my concern is that not asking enough questions risks policy development descending to the desperation tactics of The Thick of It.

\section{Relationship between ministerial advisers and the public service}

There has been real progress in clarifying the role of ministerial advisers since the Code of Conduct for Ministerial Staff was introduced in 2008. To be effective, departments need to work closely with ministerial advisers and having clarity on their respective roles is vital. The Code states that: 'Ministerial staff do not have the power to direct APS employees in their own right and that APS employees are not subject to their direction,' and that 'executive decisions are the preserve of Ministers and public servants and not ministerial staff acting in their own right.'

In his work on the postmodern presidency, Richard Rose suggests that advisers fall into four groups. ${ }^{4}$

3 Circular 2008/7 Code of Conduct for Ministerial Staff tabled in the Senate by the Special Minister of State, Senator Faulkner, 26 June 2008, Australian Public Service Commission.

4 Adapted from Richard Rose The Postmodern President, 1991 Chatham House p 171. 


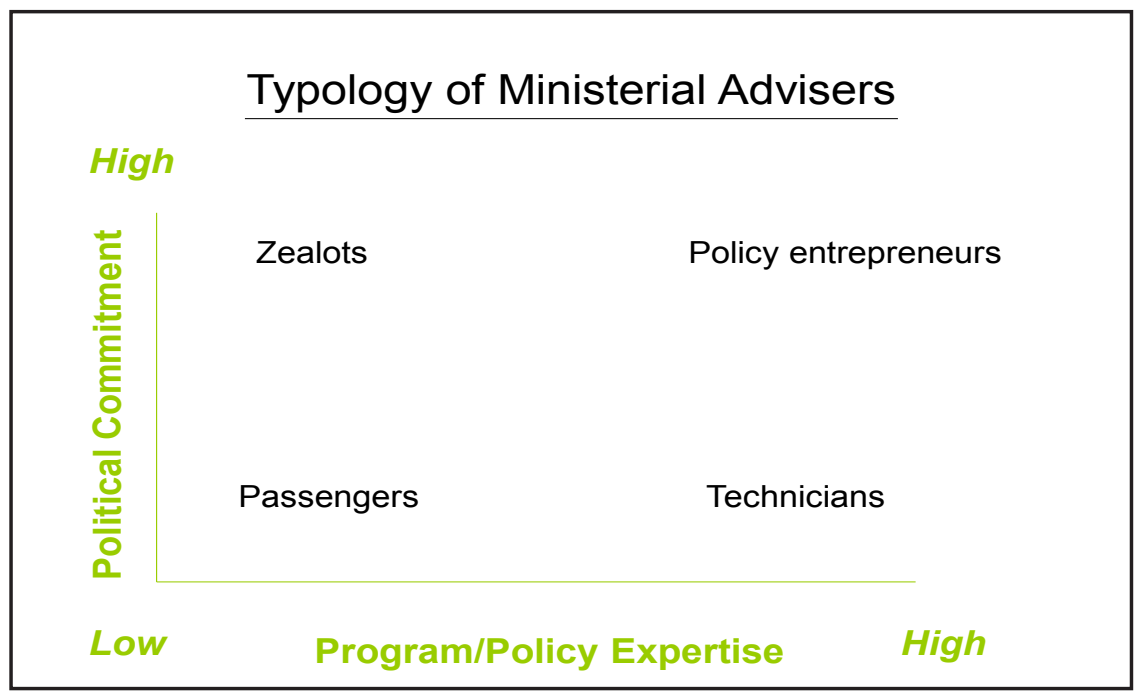

\section{Figure 1: Typology of ministerial advisers}

Clearly, having senior people in a minister's office who have both policy expertise and the confidence of the minister is preferable to the all-too-common experience of the adviser that is exclusively a political operative with little policy experience, overflowing confidence in their ability to discern policy on the basis of a quick Google search and an unrelenting focus on the short-term political imperatives (the zealots in the above typology).

There is much to be said for ensuring in ministerial offices a 'cross-fertilisation' of ideas and experiences between political operatives, senior departmental policy officers and people with diverse work and life experiences. The Hawke, Keating and Howard governments, for example, benefited from senior departmental officers playing key roles in senior ministerial offices (Dennis Richardson, Sandy Hollway, Rod Sims, Lynelle Briggs and Arthur Sinodinos just to name a few).

The Australian Public Service Commission should offer the government, the opposition and minor parties in parliament highly-regarded senior policy officers for advising roles, at times on a short-term secondment basis and of course subject to strict confidentiality arrangements. This would be seen as part of a rising career path rather than throwing your lot in with a particular party.

At present, while there is some recruitment of usually junior staff from the APS into ministers' and MP's offices, and talented junior officers are made available by departments as departmental liaison officers in ministers' offices, senior advising positions are most likely to be held by political apparatchiks. A greater mix would lead to better policies and a better appreciation of the challenges 
of implementation. How can the opposition and then new governments avoid over-promising and under-delivering if they don't have advisers with sufficient policy and implementation experience?

Not only would the placement of more senior public servants in ministerial offices assist informed policy decision-making, it would also aid the Australian Public Service in terms of interaction and insight. For a year or so I worked as a ministerial adviser in the Assistant Treasurer's office under the Keating government focusing on competition policy reform. Looking back now, that office's policy staff was largely drawn from Treasury, the Department of the Prime Minister and Cabinet and the Australian Taxation Office. Without exception those public service advisers rose to very senior ranks, have served governments of both persuasions faithfully and were better advisers because of the different perspectives gained on policy issues and exposure to the stress and strains of political life.

\section{Ensuring continued strengths}

The Australian Public Service has a long and proud history of providing strong and confidential advice. Within their confidential circles, sensible ministers and governments encourage a diversity of views. I have great respect for those ministers who welcomed confidential debate and valued criticisms of policy proposals and existing programs and were prepared to engage on alternative options.

It is easy to create a veneer of greater openness by reforming Freedom of Information laws but then have a minister insist that the most sensitive material is never provided in writing or have political advisers inappropriately seek to reprimand departmental officers for committing views to paper that would be 'unhelpful' if they were made public. At the same time, self-censorship by public servants in advising is a dangerous trap that is easy to fall into.

I am delighted that I took the decision to work in the Australian Public Service. It has remarkable strengths - these are most easily on display to the public in the efficient and remarkably reliable payment system of Centrelink (imagine the uproar if Medicare and Centrelink were unable to process funds safely, as some banks have encountered recently). My experience in policy and especially in establishing the federal Department of Human Services, and in working with large and small delivery agencies, is that there is tremendous talent and dedication within the service. For example, I saw during the recovery efforts after Cyclone Larry the tireless dedication and real innovation of the APS in serving the Australian public. 
I am delighted to have the opportunity to work in and with so many departments and agencies, and consider the APS is an important underpinning for Australia's wellbeing.

But times change and new arrangements bring different risks. In light of the increasingly substantial funds now dispersed through contracts both by officials and Commonwealth entities, I consider that it would be prudent for anti-corruption arrangements like NSW's Independent Commission Against Corruption to be established in relation to the handling of Commonwealth expenditure.

Governments are as partial to fads and fashions as teenagers. A strong and vibrant Australia needs government adherence to good cabinet processes. It also needs a strong, vibrant and impartial Australian Public Service that is always prepared to question, analyse and, where necessary, offer sometimes unwelcome but confidential advice and to implement programs as if their family's and other taxpayers' funds and services are at stake (which they are!). 
